\title{
PRAKTIK KONSERVATISME AKUNTANSI MELALUI MEKANISME CORPORATE GOVERNANCE TERHADAP KUALITAS LABA
}

\author{
Tumpal Manik (tmanik.umrah.ac.id) \\ Universitas Maritim Raja Ali Haji (UMRAH)
}

\begin{abstract}
ABSTRAK
Penelitian ini bertujuan untuk menganalisis pengaruh praktik konservatisme akuntansi dengan ukuran akrual dalam mekanisme corporate governance terhadap kualitas laba, pengaruh konservatisme akuntansi dengan ukuran nilai pasar dalam mekanisme corporate governance terhadap kualitas laba, pengaruh kualitas laba berpengaruh terhadap nilai perusahaan pada perusahaan manufaktur yang terdaftar di BEI selama tiga tahun dari tahun 2014-2016, jumlah data penelitian 273. Pengolahan data diuji dengan statistik melalui asumsi klasik dan uji hipotesis dengan Uji T, Uji F dan uji Determinasi. Hasil penelitian membuktikan bahwa konservatisme akuntansi berpengaruh signifikan terhadap kualitas laba sebesar 23,3\%. konservatisme akuntansi dengan ukuran akrual dalam mekanisme corporate governance berpengaruh signifikan terhadap kualitas laba sebesar $27,10 \%$ dan konservatisme akuntansi dengan ukuran nilai pasar dalam mekanisme corporate governance berpengaruh signifikan terhadap kualitas laba sebesar $24,3 \%$ Hasil pengujian hipotesis secara bersamaan (simultan) variabel, bahwa hipotesis nilai $F_{\text {hitung }}$ sebsesar 864,260 sedangkan nilai signifikan F-nya adalah sebesar 0,000 yang artinya bahwa nilai signifikan $F$ lebih kecil dari $a=0,05$ maka hipotesisis ini membuktkan bahwa secara bersamaan varibel konservatisme akuntansi, konservatisme akuntansi dengan ukuran akrual dan konservatisme akuntansi dengan ukuran nilai pasar berpengaruh signifikan terhadap kualitas laba.
\end{abstract}

Kata Kunci : Konservatisme Akuntansi, corporate governance, kualitas laba

\section{PENDAHULUAN}

Standar akuntansi keuangan masih mengijinkan prinsip konservatisme menyusun laporan keuangan, hal ini tidak menutup kemungkinan perlakukan melalui mekanisme corporate governance berusaha dengan segala cara menyajikan informasi dalam laporan keuangan sesempurna mungkin kepada pihak internal maupun pihak eksternal untuk mempertahankan kualitas laba dalam meningkatkan nilai perusahaan. Prinsip konservatisme ini fleksibilitas dan menjadi peluang bagi para manajemen menentukan metode maupun estimasi akuntansi yaitu kehati-hatian penyusunan laporan keuangan dengan angka-angka laba yang rendah dan angka biaya yang tinggi. Kehati-hatian penyusunan laporan keuangan adalah tidak melaporkan informasi yang mempunyai resiko besar, hal ini akan berpotensi bagi para pimpinan melalui mekanisme corporate governance untuk menyajikan informasi keuangan yang sesuai dengan harapan pimpinan untuk meningkatkan laba dan nilai perusahaan.

Penerapan akuntansi konservatif juga dimungkinkan dipengaruhi oleh adanya tekanan terhadap bisnis perusahan yang ditunjukan dengan adanya kesulitan keuangan, termasuk kontrak kompensasi antara prinsipal dengan agen yang ditunjukan dengan kepemilikan manajerial juga dapat berpengaruh terhadap konservatisme akuntansi. Konservatisme akuntansi

Hal. 1 
berpengaruh signifikan terhadap kualitas laba sebesar $17,2 \%$ sedangkan Good Corporate Governance tidak berpengaruh pada kualitas laba (Tuwentina, Putu dan Gede 2014).

Prinsip konservatisme akuntansi yang fleksibilitas dapat dimanfaatkan melalui mekanisme corporate governance dalam menentukan metode akuntansi meningkatkan kualitas laba, karena praktik prinsip konservatisme akan memperlambat pengakuan pendapatan, tetapi biaya yang terjadi lebih cepat diakui. Akibatnya, laba yang ada dalam laporan keuangan cenderung terlalu rendah dalam periode sekarang dan overstatement terhadap laba pada periode. Konservatisme akuntansi menganut prinsip memperlambat pengakuan pendapatan serta mempercepat pengakuan biaya yang mungkin terjadi. Perlakukan dalam praktik konservatisme kecenderungan akuntan untuk membutuhkan verifikasi pada tingkat yang lebih tinggi untuk keuntungan daripada kerugian melalui praktik kehati-hatian atas ketidakpastian untuk mencoba memastikan bahwa ketidakpastian tersebut dan risiko yang melekat dipertimbangkan secara memadai.

Melalui mekanisme corporate governance bahwa konservatisme akuntansi ukuran akrual dan nilai pasar tidak hanya berkaitan dengan pemilihan metode akuntansi termasuk cara manajemen memperbaiki kualitas laba untuk meningkatkan nilai perusahaan guna memberikan proteksi yang baik bagi investor, hal inilah yang menjadikan peneliti tertarik melakukan penelitian ini dengan judul "Praktik Konservatisme Akuntansi Melalui Mekanisme Corporate Governance Terhadap Kualitas Laba".

Berdasarkan uraian pendahuluan diatas, maka perumusan masalah dalam penelitian ini adalah, antara lain 1) apakah praktik konservatisme akuntansi berpengaruh terhadap nilai perusahaan. 2) apakah praktik konservatisme akuntansi dengan ukuran akrual dalam mekanisme corporate governance berpengaruh terhadap kualitas laba dan 3) apakah praktik konservatisme akuntansi dengan ukuran nilai pasar dalam mekanisme corporate governance berpengaruh terhadap kualitas laba, sedangkan tujuan penelitian ini adalah untuk mengetahui pengaruh praktik konservatisme akuntansi dengan ukuran akrual dalam mekanisme corporate governance dan ukuran nilai pasar dalam mekanisme corporate governance terhadap kualitas laba, secara parsial dan simultan.

\section{LANDASAN TEORI}

\section{Praktik Konservatisme Akuntansi}

Prinsip konservatisme juga seringkali dikaitkan dengan kualitas laba dan menjadi nilai perusahaan. Konservatisme dapat didefinisikan sebagai tendensi yang dimiliki oleh seorang akuntan yang mensyaratkan tingkat verifikasi yang lebih tinggi untuk mengakui laba (good news in earnings) dibandingkan dengan mengakui rugi (bad news in earnings) (Basu, 1997). Secara tradisional, konservatisme dalam akuntansi dapat diterjemahkan melalui pernyataan "tidak mengantisipasi keuntungan, tetapi mengantisipasi semua kerugian" (Bliss, 1924 dalam Watts, 2003),

Beberapa metoda dalam Penyataan Standar Akuntansi Keuangan (PSAK) terhadap penerapan prinsip konservatisma; a) PSAK No.13 mengenai akuntansi untuk investasi, menyatakan bahwa biaya dapat ditentukan berdasarkan FIFO, rata-rata tertimbang, atau LIFO. Nilai pasar dapat ditentukan portofolio agregat, dalam total atau menurut urutan kategori investasi, atau investasi individual, secara konsisten, b) PSAK No.14 memberikan kebijakan kepada manajemen, bahwa manajemen perusahaan dapat mencatat dan menghitung biaya persediaan dengan menggunakan salah satu metode dengan menggunakan rumus FIFO, LIFO dan rata- rata tertimbang. c) PSAK No.16 mengijinkan manajemen untuk mengestimasi masa 
manfaat suatu aset tetap berdasarkan pertimbangan yang berasal dari pengalaman perusahaan ketika menggunakan aktiva serupa. Aset tetap dan penyusutan yang mengatur estimasi masa manfaat suatu aktiva tetap.

Standar ini memungkinkan perusahaan untuk mengubah masa manfaat aktiva yang digunakan dan dapat mendorong timbulnya laba yang konservatif, seperti yang terdapat dalam a) PSAK No. 17 mengijinkan manajemen memilih metode penyusutan untuk mengalokasikan jumlah aktiva yang bisa disusutkan dengan suatu dasar sistematis sepanjang masa manfaatnya. Metode yang digunakan dipilih berdasarkan pola yang diharapkan atas manfaat keekonomian dan secara konsisten digunakan dari periode ke periode kecuali terdapat perubahan dalam pola yang diharapkan atas manfaat ekonomis aktiva tersebut. b) PSAK No. 19 mengenai aset tidak berwujud yang berkaitan dengan amortisasi. Dijelaskan bahwa terdapat beberapa metode amortisasi untuk mengalokasikan jumlah penyusutan suatu aset atas dasar yang sistematis sepanjang masa manfaatnya. PSAK No. 19 meminta manajemen untuk memilih metode amortisasi garis lurus untuk aktiva berwujud, kecuali jika suatu perusahaan mempunyai metode lain yang lebih sesuai dengan kondisi perusahaan secara teratur untuk menentukan apakah peristiwa dan kondisi perusahaan yang bersangkutan. Periode amortisasi harus dapat dievaluasi oleh perusahaan secara teratur untuk menentukan apakah peristiwa dan kondisi selanjutnya menuntut perubahan taksiran masa manfaat yang telah ditentukan. c) PSAK No. 20 mengatur biaya riset dan pengembangan, meminta pembebanan langsung biaya riset dan pengembangan yang tidak memberikan manfaat ekonomis di masa depan pada perioda terjadinya transaksi.

Praktik konservatisme tetapi tidak seluruhnya merupakan konservatisme menurut Pernyataan Akuntansi Berterima Umum (PABU) yang di atur meliputi: a) PSAK No. 20 standar ini selain mengatur kapitalisasi biaya riset dan pengembangan, juga meminta pembebanan langsung biaya riset dan pengembangan yang tidak memberikan manfaat ekonomis di masa depan pada periode terjadinya. Sehingga manajer hanya dapat sedikit melakukan diskresi atau tidak sama sekali terhadap pelaporan keuangan saat pengeluaran dilakukan. b) PSAK No. 57 (Revisi 2000) memperkenankan perusahaan mengakui kewajiban estimasian tapi tidak memberikan peluang pengakuan kemungkinan adanya aktiva estimasian. Hal ini memungkinkan manajer perusahaan untuk melaporkan secara konservatif laporan keuangannya. Perbedaan industri serta preferensi manajer.

Menurut Penman dan Zhang (2002), berpendapat bahwa konservatisme akuntansi akan mempengaruhi baik kualitas laba yang dilaporkan dalam laporan keuangan maupun kualitas akun finansial (seperti aset dan hutang) yang dilaporkan dalam neraca perusahaan. Dengan menggunakan prinsip yang konservatif dalam proses pelaporan keuangan maka laba yang dihasilkan akan memiliki kualitas yang tinggi karena konservatisme mensyaratkan tingkat verifikasi yang lebih tinggi untuk mengakui laba dibandingkan dengan mengakui rugi (Basu, 1997).

Menurut Gul et al (2002), konservatisme adalah reaksi yang hati-hati dalam menghadapi ketidakpastian, dimana dalam menghadapi ketidakpastian perusahaan mempertimbangkan risiko yang inhern dalam lingkungan bisnis, hal ini dipertegas oleh Handojo (2012) yang meyatakan bahawa konservatisme menyebabkan data yang dilaporkan tidak bisa dinterpretasikan secara tepat, karena yang dilaporkan dalam laporan keuangan mengenai angka-angka yang rentang untuk hal-hal yang menguntungkan namun angka yang relatif tinggi untuk hal-hal yang merugikan.

Tiga tujuan konservatisme yang diuraikan oleh Watts (2003), antara lain adalah (1) Membatasi manajer dalam berperilaku oportunistik. Manajer yang mempunyai tanggungjawab

Hal. 3 
terhadap laporan keuangan kepada investor dalam hal pengambilan keputusan, membuat manajemen cenderung mempengaruhi angka-angka dalam laporan keuangan untuk kepentingan manajemen. Dalam hal ini konservatisme bisa membatasi perilaku manajemen untuk bertindak oportunistik, (2) Meningkatkan nilai perusahaan. Dengan membatasi adanya perilaku oportunistik dari manajemen maka nilai perusahaan dapat meningkat, (c) Mengurangi potensi tuntutan hukum; Peningkatan laba yang terlalu tinggi mendorong tingginya tuntutan hukum yang harus dilaksanakan, dengan adanya hal tersebut maka mendorong manajemen bertindak konservatif. (3) Mentaati peraturan, Peraturan yang dibuat oleh penyusun standar, memberikan perusahaan untuk melakukan penetapan metoda peniliaian persediaan pada harga yang fluktuatif.

Belkoui (2007), mendefinisikan konservatitif adalah sebagai prinsip bagi akuntan yang harus melaporkan informasi akuntansi baik aktiva dan pendapatan dari kemungkinan nilai dari kewajiban dan beban. Konservatisme akuntansi dapat diukur dengan menggunakan beberapa ukuran. Beberapa literatur telah menyebutkan berbagai cara untuk mengukur tingkat konservatisme dalam perusahaan. Proxi dari ukuran konservatisme dapat berupa ukuran spesifik perusahaan yaitu ukuran berdasarkan nilai akrual sesuai dengan Givoly dan Hayn (2000), dan ukuran yang berdasarkan nilai pasar sesuai dengan Beaver dan Ryan (2000). Selain itu konservatisme akuntansi dapat pula diukur dengan menggunakan ukuran asymmetric timeliness dari pengakuan laba dan rugi sesuai dengan Basu (1997).

Beberapa contoh area yang prinsip konservatisme akuntansi kemungkinan masih dipertahankan, antara lain: (1) Kompensasi kerugian menyebabkan pengakuan piutang pajak tangguhan. Aset pajak tangguhan diakui untuk akumulasi rugi pajak belum dikompensasi apabila besar kemungkinan laba kena pajak masa depan akan memadai untuk dimanfaatkan dengan rugi pajak belum dikompensasi. Kriteria probabilitas (kemungkinan) merupakan kriteria kualitatif yang bersifat subjektif dimana dengan adanya kriteria subjective judgement ini terbuka peluang untuk menerapkan konservatisme. (2) Kapitalisasi biaya pengembangan. Salah satu syarat aset tak berwujud yang timbul seperti biaya pengembangan (atau dari tahap pengembangan pada proyek internal) diakui apabila memenuhi bagaimana aset tak berwujud tersebut akan menghasilkan kemungkinan besar manfaat ekonomi masa depan.

Implementasi atas asas konservatisme yaitu jika terdapat sesuatu yang dapat meningkatkan aktiva, tetapi belum terealisasi, maka kejadian itu belum boleh diakui. Tetapi jika terdapat sesuatu yang mengakibatkan penurunan aktiva, walaupun belum terealisasi, maka kejadian itu harus sudah diakui. Dalam sebuah perusahaan memperbarui estimasi mengenai arus kas masa depan dari biaya pengembangan yang dikapitalisasinya, mungkin ada efek sementara konservatisme yang mengarah pada penciptaan cadangan tersembunyi yang kemudian dapat dibalik kembali (Reversed). Penyajian informasi keuangan dihadapkan pada prinsip kehati-hatian, yakni terhadap pencatatan pendapatan dan biaya, maupun pencatatan terhadap aktiva.

\section{Konservatisme Akuntansi Melalui Mekanisme Corporate Governance}

Konservatisme akuntansi melalui corporate governance merupakan salah satu karakteristik dewan yang berhubungan dengan kandungan informasi laba. Konservatisme akuntansi sebagai kemampuan untuk memverifikasi perbedaan yang diperlukan agar bisa membuktikan apakah yang didapatkan adalah laba atau rugi, sedangkan Subramanyam (2010), menyatakan bahwa salah satu ukuran kinerja perusahaan yang sering digunakan sebagai dasar pengambilan keputusan adalah kualitas laba yang dihasilkan. Menurut Febiani (2012), ditemukan bahwa 3 mekanisme Good Corporate Governance yaitu kepemilikan institusional, kepemilikan manajerial, dan kualitas audit secara parsial berpengaruh positif pada kualitas laba. 


\section{Komisaris Independen}

Perusahaan perlu memiliki komisaris independen yang memiliki keahlian di bidangnya dan latar belakang akuntansi atau keuangan, agar fungsi pengawasan dapat berjalan dengan baik. Dengan adanya komisaris yang independen, pengawasan yang dilakukan oleh dewan komisaris akan lebih ketat sehingga akan cenderung mensyaratkan akuntansi yang konservatif untuk mencegah sikap oportunistik manajer.

Berdasarkan teori agensi klasik, semakin besar kepemilikan oleh komisaris yang terafiliasi akan mengarahkan pada kesesuaian tujuan antara pihak manajemen dengan pemegang saham. Namun, di lain pihak sebagai pemilik, komisaris yang terafiliasi dapat mempergunakan kekuatan votingnya untuk melakukan ekspropriasi terhadap perusahaan (Wardhani, 2008). Dewan komisaris dan komite audit, sebagai struktur corporate governance, mempunyai peran yang sangat penting dan strategis dalam hal memelihara kredibilitas proses penyusunan laporan keuangan seperti halnya menjaga terciptanya sistem pengawasan perusahaan yang memadai serta dilaksanakannya good corporate governance. Berjalannya fungsi dewan komisaris dan komite audit secara efektif, maka kontrol terhadap perusahaan akan lebih baik sehingga konflik keagenan yang terjadi antara pemegang saham mayoritas dan managemen dengan pemegang saham minoritas dapat diminimalisasi.

\section{Kepemilikan Manajemen}

Secara teoritis ketika kepemilikan manajemen rendah, maka insentif terhadap kemungkinan terjadinya perilaku oportunistik manajer akan meningkat. Kepemilikan manajemen terhadap saham perusahaan dipandang dapat menyelaraskan potensi perbedaan kepentingan antara pemegang saham luar dengan manajemen. Penggunaan konsep konservatisme berkaitan pula dengan struktur kepemilikan manajerial pada sebuah perusahaan. Struktur kepemilikan manajerial merupakan persentase jumlah saham yang dimiliki oleh perusahaan dibandingkan dengan jumlah saham yang dimiliki oleh pihak eksternal.

\section{Komite Audit}

Komite audit yang bertanggung jawab untuk mengawasi laporan keuangan, mengawasi audit eksternal, dan mengamati sistem pengendalian internal (termasuk audit internal) dapat mengurangi sifat opportunistic manajemen yang melakukan manajemen laba (earnings management) dengan cara mengawasi laporan keuangan dan melakukan

pengawasan pada audit eksternal (Siallagan dan Machfoedz, 2006). Komite audit sebagai pengendali dalam perusahaan, namun praktik konservatisma melalui komite audit sering mengharapakan informasi manajer, maka manajer mempunyai kecenderungan untuk mengecilkan laba yang dilaporkan untuk mengurangi biaya politis yang potensial. Umumnya dalam motivasi ini, konservatisme akuntansi didorong untuk mengurangi atau menunda pajak dan untuk menghindari regulasi, yang disebut juga sebagai biaya politis. Semakin besar biaya politis yang dihadapi perusahaan, maka semakin cenderung manajer memilih prosedur akuntansi yang melaporkan laba yang lebih rendah.

Salah satu cara komisaris mempertahankan independensinya adalah dengan membentuk komite audit. Sesuai dengan fungsi komite audit di atas, sedikit banyak keberadaan komite audit dalam perusahaan berpengaruh terhadap kualitas dan integritas

laporan keuangan yang dihasilkan. Keberadaan komite audit sangat penting bagi pengelolaan perusahaan. Komite audit merupakan komponen dalam sistem pengendalian perusahaan. Selain itu komite audit dianggap sebagai penghubung antara pemegang saham dan dewan komisaris dengan pihak manajemen dalam menangani masalah pengendalian. 


\section{Kepemilikan Institusional}

Kepemilikan oleh investor institusional yang tinggi dapat menggantikan atau memperkuat fungsi monitoring dari dewan komisaris oleh perusahaan. Hal ini dikarenakan kepemilikan oleh investor institusional merupakan mekanisme alternatif dalam corporate governance (Warhani, 2008). Perusahaan yang besar akan menghadapi biaya politis yang tinggi, sehingga untuk mengurangi biaya politis tersebut maka perusahaan akan lebih menggunakan prinsip akuntansi yang konservatif. Menurut Watts dan Zimmerman dalam Wardhani (2008), ukuran perusahaan akan mempengaruhi tingkat biaya politis yang dihadapi perusahaan sehingga akan mempengaruhi penggunaan prinsip akuntansi yang konservatif. Kemudian, hasil penelitian Indrawati dan Yuli (2010), membuktikan bahwa hanya kepemilikan institusional yang berpengaruh signifikan terhadap kualitas laba.

Praktik konservatisme bisa terjadi karena standar akuntansi yang berlaku di Indonesia memperbolehkan perusahaan untuk memilih salah satu metode akuntansi dari kumpulan metode yang diperbolehkan pada situasi yang sama. Praktik akuntansi dalam kepemilikan institusional untuk kontrak utang, kos potlitis dan pertumbuhan, kecuali. kontrak utang. Jika investor institusional mempunyai kepemilikan saham dalam jumlah besar, maka mereka mempunyai hak untuk mengawasi perilaku dan kinerja manajemen. Investor cenderung berharap investasi yang mereka tanamkan di dalam perusahaan aman dan mempunyai tingkat return yang tinggi, hal ini mendorong manajemen untuk melaporkan laba yang tidak konservatif agar pembagian dividen tinggi. Selain itu juga menarik para calon investor baru untuk menanamkan investasinya.

\section{Ukuran Perusahaan}

Ukuran perusahaan akan mempengaruhi tingkat biaya politis yang dihadapi perusahaan sehingga akan mempengaruhi penggunaan prinsip akuntansi yang konservatif. Ukuran perusahaan dapat dihitung dengan menggunakan rata-rata total asset. Ukuran perusahaan akan mempengaruhi tingkat biaya politis yang dihadapi perusahaan sehingga akan mempengaruhi penggunaan prinsip akuntansi yang konservatis (Watts dan Zimmerman, 1978).

\section{Kualitas Laba}

Kualitas laba merupakan konsep yang multidimensi dapat dilihat dari kriteria penyajian kejujuran dan tepat waktu laporan keuangan tanpa mengedepankan prinsip konservatisme, Tujuan utama perusahaan, adalah meningkatkan nilai perusahaan. Rendahnya kualitas laba akan dapat membuat kesalahan pembuatan keputusan para pemakainya seperti investor dan kreditor, sehingga nilai perusahaan akan berkurang (Machfoedz dan Siallagan, 2006), sehingga pencatatan konsep konservasitisme akuntasi ukuran akrual tidak terlepas dari faktor internal melalui mekanisme good corporate governance. Dampak dari corporate governance terhadap kualitas laba yang salah satu ukurannya adalah konservatisme dalam pelaporan keuangan Wu (2006).

Terdapat beberapa proksi yang dapat digunakan dalam pengukuran kualitas laba antara lain persistensi laba, Discretionary Accruals, ketepatan waktu, dan Earnings Respons Coefficients (Dechow, 2010). Menurut Sadidi et al. (2011), menemukan bahwa indeks kualitas laba yang disajikan berdasarkan indeks konservatisme memiliki kemampuan untuk menggambarkan beberapa perbedaan antara return aset operasional dan return saham saat ini dari tahun ini sampai tahun berikutnya, sehingga mencerminkan laba yang berkualitas, sedangkan menurut Fala (2007), bahwa terdapat hubungan positif signifikan antara konservatisme akuntansi terhadap penilaian ekuitas. 
Kualitas laba atas praktik konservatisme akuntansi bertujuan agar laba laba dapat merefleksikan dampak ekonomis yang sesungguhnya dari suatu transaksi. Kualitas laba merupakan konsep yang multidimensi yang dapat dilihat dari berbagai sudut pandang. Dalam penelitian ini, laba dikatakan berkualitas apabila memenuhi beberapa kondisi seperti memiliki kemampuan prediksi, bersifat netral, disajikan secara tepat waktu, disajikan secara jujur, dan mengedepankan prinsip konservatisme. Kualitas laba berkaitan dengan kegunaan informasi akuntansi bagi pengguna laporan keuangan. Kualitas laba dapat membedakan antara informasi yang superior (lebih bermanfaat) dengan informasi yang inferior (kurang bermanfaat).

Laba sebelum extraordinary items dimaksudkan untuk menghilangkan elemen yang menyebabkan pertumbuhan laba meningkat dalam satu periode yang tidak akan timbul dalam periode lainnya. Apabila laba yang dihasilkan lebih rendah daripada arus kas operasi maka menunjukkan diterapkannya prinsip konservatisme. Hal ini berarti perusahaan semakin banyak menangguhkan pendapatan yang belum terealisasi dan semakin cepat membebankan biaya.

\section{Nilai Perusahaan}

Semakin negatif tingkat akrual rata-rata selama periode tertentu, maka prinsip akuntansi yang digunakan semakin konservatif. Givoly dan Hayn (2002) dalam Sari dan Adhariani (2009), melihat kecenderungan dari akun akrual selama beberapa tahun. Apabila terjadi akrual negatif (net income lebih kecil daripada cash flow operasional) yang konsisten selama beberapa tahun, maka merupakan indikasi diterapkannya konservatisme.

Nilai yang digunakan sebagai proksi dari tingkat konservatisme dalam penelitian ini adalah nilai rata-rata selama tiga tahun dengan nilai tengah pada periode $t$, dikali dengan negatif satu untuk memastikan bahwa nilai yang positif mengindikasikan tingkat konservatisme yang lebih tinggi Hal ini dilandasi oleh teori bahwa konservatisme menunda pengakuan pendapatan dan mempercepat pengakuan biaya. Sehingga laporan laba rugi yang konservatis akan menunda pengakuan pendapatan yang belum terealisasi dan biaya yang terjadi pada periode tersebut akan segera dibebankan pada periode tersebut dibandingkan menjadi cadangan (biaya yang ditangguhkan) pada neraca.

\section{Pengembangan Hipotesis}

Konservatisme akuntansi implementasi dari kehati-hatian penyusunan laporan keuangan tidak berlebihan melaporkan informasi yang mempunyai resiko besar Interpretasi konservatisme akuntansi sebagai kehati-hatian (prudent), akuntansi tidak lagi mengungkapkan secata tepat true value tetapi cenderung menetapkan angka laporan yang lebih rendah dari true value (Handojo, Irwanto, 2011).

\section{Pengaruh Praktik Konservatisme Akuntansi Dengan Ukuran Akrual Dalam Mekanisme Corporate Governance Terhadap Kualitas Laba.}

Konservatisme akuntansi melalui corporate governance merupakan salah satu karakteristik dewan yang berhubungan dengan kandungan informasi laba. Konservatisme akuntansi sebagai kemampuan untuk memverifikasi perbedaan yang diperlukan agar bisa membuktikan apakah yang didapatkan adalah laba atau rugi. Menurut Subramanyam (2010), menyatakan bahwa salah satu ukuran kinerja perusahaan yang sering digunakan sebagai dasar pengambilan keputusan adalah kualitas laba yang dihasilkan.

Konservatisme akuntansi merupakan asimetri dalam permintaan verifikasi terhadap laba dan rugi. Interprestasi tersebut berarti bahwa semakin besar perbedaan tingkat verifikasi yang diminta 
terhadap laba dibandingkan terhadap rugi, maka semakin tinggi tingkat konservatisme akuntansi. Mengantisipasi laba berati mencatat laba sebelum ada klaim secara hukum dihubungkan dengan aliran kas dimasa yang akan datang dan sebaliknya tidak mengantisipasi laba berati belum mencatat laba sebelum ada klaim secara hukum dihubungkan dengan aliran kas dimasa yang akan datang (Watts, 2003 dalam Kiryanto dan Supriyanto, 2006).

Mekanisme corporate governance melalui komisaris terdiri dari : independen, kepmilikan direksi, komisaris auditor, kepemilikan institusional, ukuran perusahaan, pertumbuhan penjualan, profitas bilitas dan laverage. Menurut Veronica (2013), konservatisme akuntansi berpengaruh signifikan positif sebesar 1,275 terhadap kualitas laba akrual, kualitas laba lebih tinggi secara konservatif karena lebih kecil kemungkinan kinerja saat ini dan perkiraan kinerja masa depan dinyatakan terlalu tinggi. Berdasarkan penjelasan analisis pengembangan hipotesis diatas, maka hipotesisi dalam penelitian ini adalah :

\section{H1: Diduga praktik konservatisme akuntansi dengan ukuran akrual dalam mekanisme corporate governance berpengaruh terhadap kualitas laba}

\section{Pengaruh Praktik Konservatisme Akuntansi Dengan Ukuran Nilai Pasar dalam Mekanisme Corporate Governance Berpengaruh Terhadap Kualitas Laba}

Ukuran konservatisme berdasarkan nilai pasar perusahaan merupakan nilai rasio book-tomarket perusahaan (Beaver dan Ryan, 2000). Nilai tersebut dikali dengan nilai negatif satu agar nilai positif mencerminkan tingkat konservatisme yang lebih tinggi. Hal ini karena apabila perusahaan menggunakan prinsip konservatisme, maka nilai buku perusahaan akan cenderung lebih rendah dibandingkan dengan nilai pasarnya sehingga rasio book-to-market akan lebih rendah dibandingkan dengan perusahaan yang tidak menerapkan prinsip konservatisme.

Ukuran konservatisme melalui mekanisme corporate governance terdiri dari : komisaris independen, kepmilikan direksi, komisaris auditor, kepemilikan institusional, ukuran perusahaan, pertumbuhan penjualan, profitas bilitas dan laverage, pengembalian sekarang dan tahun lalu. konservatisme dengan nilai pasar atau sebagai harga pasar yang dirgresikan dalam corporate goverance. Mengendalikan dampak pertumbuhan penjualan menyatakan bahwa pertumbuhan penjualan akan mempengaruhi praktik konservatisme melalui ukuran akrual dan nilai pasar karena pertumbuhan penjualan akan mempengaruhi tingkat akrual perusahaan seperti persediaan dan piutang dan pertumbuhan penjualan yang tinggi seringkali meningkatkan ekspektasi pasar terhadap arus kas di masa depan sehingga akan mempengaruhi ukuran konservatisme melalui nilai pasar (Ahmed dan Duellman, 2007).

Pemilihan metode akuntansi konservatif tidak terlepas dari kepentingan manajemen untuk memaksimalkan kepentingan dengan mengorbankan kesejahteraan pemegang sahamnya, atau yang biasa disebut dengan masalah keagenan seperti yang tersaji dalam teori keagenan. Pertumbuhan ini akan direspon positif oleh investor sehingga nilai pasar perusahaan konservatif lebih besar dari nilai bukunya sehingga akan tercipta goodwill. Hal ini akan membuat pasar dan investor menilai positif terhadap perusahaan. Keadaan ini dapat memperlihatkan perusahaan yang selalu tumbuh karena aset yang selalu bertambah. Hal ini disebabkan oleh prinsip-prinsip konservatisme yang berpihak kepada investor dengan cenderung bersifat melindungi investor dari kesalahan berinvestasi akibat kekeliruan dalam menganalisis informasi laba perusahaan

Melalui mekanisme corporate governance bahwa konservatisme akuntansi nilai pasar tidak hanya berkaitan dengan pemilihan metode akuntansi termasuk cara manajemen memperbaiki kualitas laba untuk meningkatkan nilai perusahaan guna memberikan proteksi yang baik bagi

Hal. 8 
investor, Berdasarkan penjelasan analisis pengembangan hipotesis diatas, maka hipotesisi dalam penelitian dirumuskan sebagai berikut :

H2: Diduga praktik konservatisme akuntansi dengan ukuran nilai pasar dalam mekanisme corporate governance berpengaruh terhadap kualitas laba

\section{Pengaruh Kualitas Laba Terhadap Nilai Perusahaan}

Kualitas laba atas praktik konservatisme akuntansi bertujuan agar laba laba dapat merefleksikan dampak ekonomis yang sesungguhnya dari suatu transaksi. Mengukur kualitas laba menggunakan model Jones melalui Discretionary Accruals (Healy, 1985 dan Dechow et al, 1995) sebagai proksi kualitas laba dihitung dengan menggunakan yang dimodifikasi karena bahwa model ini dianggap lebih baik diantara model yang lain untuk mengukur manajemen laba. Discretionary Accrual (DACC) digunakan sebab estimasi discretionary accruals dapat diukur secara langsung untuk menentukan kualitas laba.

Menurut Rika, (2012), faktor lain yang mempengaruhi nilai perusahaan, selain informasi laporan keuangan. Jika kualitas laba yang tinggi akan meningkatkan nilai perusahaan, maka kualitas laba dapat menguatkan hubungan antara kinerja keuangan dengan nilai perusahaan. Semakin tinggi kualitas laba maka diduga kinerja keuangan, sedangkan menurut Paulus and Hadiprajitno (2011), Semakin kecil discretionary accruals semakin tinggi kualitas laba dan sebaliknya. Laba akuntansi akan dicatat dan diuraikan dalam arus kas operasi dan accruals. Acccruals terdiri dari discretionary dan non discretionary accruals. Discretionary accruals merupakan penyesuaian arus kas oleh manajer dari serangkaian kesempatan prosedur akuntansi yang disusun oleh manajemen.

Bagi perusahaan yang menerbitkan saham di pasar modal harga saham yang ditransaksikan di bursa merupakan indikator nilai perusahaan. Laba yang tidak menunjukkan informasi yang sebenarnya tentang kinerja manajemen dapat menyesatkan pihak pengguna laporan. Jika laba seperti ini digunakan oleh investor untuk membentuk nilai pasar perusahaan, maka laba tidak dapat menjelaskan nilai pasar perusahaan yang sebenarnya (Rachmawati dan Triatmoko Hanung, 2007), sedangkan menurut Siallagan dan Machfoed (2006), yang menguji pengaruh kualitas laba terhadap nilai perusahaan pada perusahaan manufaktur menyimpulkan bahwa kualitas laba secara positif berpengaruh terhadap nilai perusahaan. Berdasarkan penjelasan teori pengembangan hipotesis diatas, maka hipotesisi dalam penelitian ini adalah :

\section{H3 : Diduga kualitas laba berpengaruh terhadap kualitas laba nilai perusahaan}

\section{Pengaruh praktik konservatisme akuntansi dengan ukuran akrual dan ukura pasar secara langsung dan tidak langsung terhadap nilai perusahaan melalui kualitas laba}

Konservatisme akuntansi terjadi karena standar akuntansi yang berlaku di Indonesia memperbolehkan untuk memilih metode akuntansi. Handojo (2012), menyatakan bahwa konservatisme menyebabkan data yang dilaporkan tidak bisa dinterpretasikan secara tepat, karena yang dilaporkan dalam laporan keuangan mengenai angka-angka yang rentang untuk halhal yang menguntungkan namun angka yang relatif tinggi untuk hal-hal yang merugikan. Prinsip konservatisme dalam pelaporan keuangan yang dimaksudkan untuk mengakui dan mengukur aktiva dan laba dilakukan dengan penuh kehati-hatian oleh karena aktivitas ekonomi dan bisnis yang dilingkupi ketidakpastian. Implikasi dari penerapan prinsip ini adalah pilihan metode akuntansi ditujukan pada metode yang melaporkan laba dan aktiva lebih rendah atau utang lebih tinggi. 
Dalam penelitian ini pengaruh praktik konservatisme akuntansi dengan ukuran akrual secara langsung dan tidak langsung terhadap nilai perusahaan melalui kualitas laba melalui metode yang ada dalam PSAK, prinsip konservatisme akuntansi yang fleksibilitas dapat dimanfaatkan melalui mekanisme corporate governance dalam menentukan metode akuntansi meningkatkan kualitas laba, karena praktik prinsip konservatisme akan memperlambat pengakuan pendapatan, tetapi biaya yang terjadi lebih cepat diakui. Akibatnya, laba yang ada dalam laporan keuangan cenderung terlalu rendah dalam periode sekarang dan overstatement terhadap laba pada periode yaitu bahwa konservatisme sebagai praktik mengurangi laba dengan mengecilkan aset bersih dalam merespons berita buruk, tetapi tidak meningkatkan laba termasuk meninggikan aset bersih dalam merespons berita baik.

Laba yang berfluktuatif memiliki daya prediksi yang lebih rendah dari pada laba yang lebih stabil untuk memprediksi aliran kas masa depan. Sehingga laba perusahaan yang menerapkan prinsip akuntansi konservatif akan memilki daya prediksi yang lebih rendah dari pada laba perusahaan yang menerapkan prinsip akuntansi yang lebih optimis. Konservatisme tersebut, kini praktik corporate governance telah menjadi sebuah isu yang menarik sejak dekade terakhir. Corporate governance merupakan suatu sistem yang mengatur dan mengendalikan perusahaan yang diharapkan dapat memberikan dan meningkatkan nilai perusahaan kepada para pemegang saham (Febiani, 2012), Mekanisme corporate governance yaitu kepemilikan manajerial, proporsi dewan komisaris independen dan komite audit. Corporate governance diperlukan untuk meningkatkan kualitas laba perusahaan. Jadi, melalui penerapan corporate governance pada sebuah perusahaan, diharapkan manajer yang akan menyusun laporan keuangan mampu. Berdasarkan penjelasan teori pengembangan hipotesis diatas, maka hipotesisi dalam penelitian ini adalah :

H4 : Diduga praktik konservatisme akuntansi dengan ukuran akrual dalam mekanisme corporate governance secara langsung dan tidak langsung berpengaruh terhadap nilai perusahaan melalui kualitas laba.

H5: Diduga praktik konservatisme akuntansi dengan ukuran nilai pasar dalam mekanisme corporate governance secara langsung dan tidak langsung berpengaruh terhadap nilai perusahaan melalui kualitas laba

\section{METODOLOGI PENELITIAN}

\section{Jenis dan Sumber Data Penelitian}

Jenis data yang digunakan dalam penelitian ini adalah data sekunder, yaitu data-data yang disediakan oleh pihak lain dan tidak berasal dari sumber langsung. Data yang diperoleh berupa laporan keuangan perusahaan manufaktur yang dipublikasikan oleh Bursa Efek Indonesia (BEI) tahun 2014 - 2016. Populasi yang digunakan dalam penelitian ini adalah semua perusahaan manufaktur yang terdaftar di Bursa Efek Jakarta (BEJ). Pengambilan sampel dilakukan dengan metode purposive sampling. Jumlah populasi 168 yang memenuhi kriteria sebanyak 91 perusahaan, maka data penelitian $91 \times 3$ tahun yaitu 273 data

\section{Metode Analisis dan Hipotesisi Penelitian}

Pengujuan pertama dengan uji statistik deskriptif, Kemudian pengujian asumsi klasik sebagai salah satu syarat untuk bisa menggunakan persamaan regresi berganda adalah terpenuhinya uji asumsi klasik. Empat uji asumsi klasik dalam penelitian ini meliputi normalitas, asumsi heteroskedastisitas, autokorelasi dan multikolinearitas. Penjelasan masing-masing pengujian asumsi klasik akan diuraikan seperti di bawah ini. Lanjutan pengujian untuk metode 
analisis yang digunakan untuk menguji pengaruh variabel bebas terhadap terikat dengan Uji T, Uji F dan Uji Determinasi

\section{Operasional Variabel Penelitian}

Variabel bebas dalam penelitian ini terdiri dari dua ukuran konservatisme yaitu ukuran menggunakan ukuran akrual dan ukuran menggunakan nilai pasar. Ukuran konservatisme dengan menggunakan akrual, sesuai dengan Givoly dan Hayn (2000). Nilai yang digunakan sebagai proksi dari tingkat konservatisme adalah nilai rata-rata selama tiga tahun dengan nilai tengah pad periode $t$, dikali dengan negatif satu untuk memastikan bahwa nilai yang positif mengindikasikan konservatisme yang lebih tinggi. Instiuisi dalam ukuran ini adalah bahwa akuntansi yang konservatif merupakan hasil dari akrual negatif yang persisten (Givoly dan Hayn, 2000). Semakin negatif tingkat akrual rata-rata selama periode tertentu, maka prinsip akuntansi yang digunakan semakin konservatif.

\section{Konservatisme Akuntansi}

Ukuran konservatisme yang digunakan dalam penelitian ini adalah ukuran akrual yang merupakan variabel terikat dalam model penelitian. Ukuran konservatisme dengan menggunakan akrual, sesuai dengan yang digunakan oleh Givoly dan Hayn (2002) dalam Ahmed dan Duellman (2007). Rumus untuk mengukur konservatisme yaitu:

$$
\text { KON_ACC }=\frac{\mathrm{NI}-\mathrm{CF}}{\mathrm{RTA}}
$$

Dimana:

KON_ACC: Tingkat konservatisme akuntansi

$\mathrm{NI} \quad$ : Laba sebelum extraordinary items

CF : Arus kas operasi ditambah biaya depresiasi

RTA : Rata-rata total aktiva

\section{Konservatisme Akuntansi Dengan Ukuran Akrual}

Mengukur tingkat konservatisme akuntansi dengan ukuran akrual menggunakan rumus dari penelitian Wardhani Ratna, (2010)
$\mathrm{KON}-\mathrm{ACC}_{\mathrm{i}, \mathrm{t}}=$
Dimana:
KON-ACC
: Tingkat konseratisme dengan ukuran akrual perusahaan i pada waktu t
INDEP_COMi,t : Proporsi Komisaris Independen terhadap jumlah total komisaris perusahaan i pada waktu $t$
BOARD_OWN $\mathrm{N}_{\mathrm{i}, \mathrm{t}}$ : Persentase kepemilikan saham oleh komisaris dan direksi perusahaan i pada waktu $t$
COM_AUD $\mathrm{i}_{\mathrm{i}, \mathrm{t}} \quad$ : Ada atau tidaknya Komite Audit pada perusahaan i pada waktu t
INS_OWNi,t : Persentase kepemilikan saham oleh institusi keuangan pada perusahaan i pada waktu $t$
FIRM_SIZE $E_{i, t} \quad$ : Rata-rata total aset perusahaan i pada waktu $t$
SALES_GROWTH $\mathrm{H}_{\mathrm{i}, \mathrm{t}}$ : Pertumbuhan penjualan perusahaan i pada waktu $\mathrm{t}$
$\mathrm{PROF}_{\mathrm{i}, \mathrm{t}} \quad$ : Profitabilitas perusahaan i pada waktu $\mathrm{t}$
LEV $\quad$ : Leverage (tingkat hutang) perusahaan i pada waktu $t$ 


\section{Konservatisme Akuntansi Dengan Ukuran Nilai Pasar}

Mengukur tingkat konservatisme akuntansi dengan ukuran nilai perusahaan (Wardhani Ratna, 2010), menggunakan rumus dari penelitian

$$
\begin{aligned}
& K O N-M K T_{i, t}=\beta_{0}+\beta_{1} I N D E P \_C O M_{i, t}+\beta_{2} \text { BOARD_OWN } N_{i, t}+\beta_{3} C O M \_A U D_{i, t} \\
& +\beta_{4} \text { INS_OWN } \mathrm{N}_{\mathrm{i}, \mathrm{t}}+\beta_{5} \text { FIRM_SIZE } \mathrm{i,t}+\beta_{6} \text { SALES_GROWTH }_{\mathrm{i}, \mathrm{t}}+ \\
& \beta_{7} P_{R O F} F_{i, t}+\beta_{8} L_{E V} V_{i, t}+\beta_{9} \text { CURR_RET } T_{i, t}+\beta_{9} L A G \_R E T_{i, t}+\varepsilon_{i, t}
\end{aligned}
$$

Dimana:

KON-ACC $\mathrm{i}_{\mathrm{i}, \mathrm{t}}$ : Tingkat konservatisme dengan ukuran pasar (rasio book-to-market)i,t perusahaan i pada waktu $t$

CURR_RET $T_{i, t}$ : Holding period return satu tahun perusahaan i pada waktu $t$

LAG_RET ${ }_{i, t} \quad$ : Return periode sebelumnya

Ekspektasi dari model diatas adalah : $\beta 1>0, \beta 2 \neq 0, \beta 3>0, \beta 4>0, \beta 5>0, \beta 6>0, \beta 7>0$, $ß 8>0, \beta 9>0, ß 10>0$

Variabel bebas dalam penelitian ini adalah kualitas laba diukur dengan menggunakan model Jones melalui Discretionary Accruals (Healy, 1985 dan Dechow et al, 1995) sebagai proksi kualitas laba dihitung dengan menggunakan yang dimodifikasi karena bahwa model ini dianggap lebih baik diantara model yang lain untuk mengukur manajemen laba. Discretionary Accrual (DACC) digunakan sebab estimasi discretionary accruals dapat diukur secara langsung untuk menentukan kualitas laba. Menurut Paulus, Christian and Hadiprajitno, (2011). Semakin kecil discretionary accruals semakin tinggi kualitas laba dan sebaliknya. Laba akuntansi akan dicatat dan diuraikan dalam arus kas operasi dan accruals. Acccruals terdiri dari discretionary dan non discretionary accruals. Discretionary accruals merupakan penyesuaian arus kas oleh manajer dari serangkaian kesempatan prosedur akuntansi yang disusun oleh manajemen. Rumus menghitung nilai Discretionary Accrual (Healy, 1985, Dechow et al, 1995; Siallagan dan Mas'ud 2006 dan Triatmoko, 2007) disetimasikan dengan persamaan berikut :

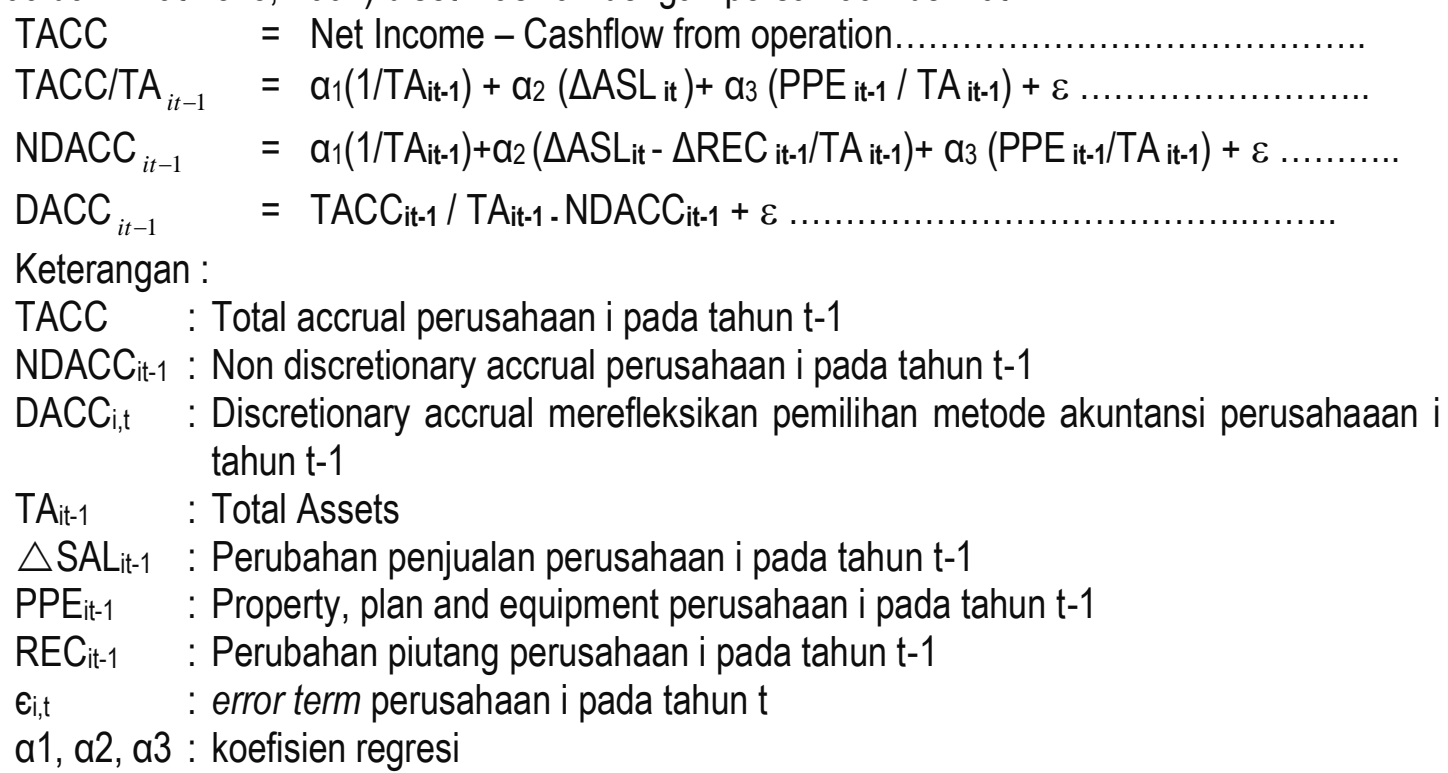




\section{HASIL DAN PEMBAHASAN}

Pengujian hipotesisi untuk membuktikan hasil penelitian yang memiliki pengaruh berdasarkan hipotesis yang telah ditetapkan sebelumnya. Dari tabel dibawah, dapat dilihat bahwa nilai $\mathrm{R}^{2}$ (koefisien determinasi) adalah sebesar 0,905 yang artinya bahwa analisis hipotesis memberikan penjelasan nilai konservatisme akuntansi dengan ukuran akrual dan nilai pasar berpengaruh terhadap kualitas laba sebesar 90,5\%. Hasil out SPSS dibuktikan dalam tabel dibawah ini.

Tabel. 2. Hasil Uji Hipotesis Penelitian

\begin{tabular}{|c|c|c|c|c|}
\hline \multicolumn{4}{|l|}{ Keterangan } & Nilai \\
\hline \multicolumn{4}{|l|}{ R Square } & 0,906 \\
\hline \multicolumn{4}{|c|}{ Adjusted R Square } & 0,905 \\
\hline \multicolumn{4}{|c|}{ F hitung } & 864,260 \\
\hline \multicolumn{4}{|l|}{ Probabilitas } & 0,000 \\
\hline Keterangan & $\begin{array}{c}\text { Unstandardized } \\
\text { Coefficients }\end{array}$ & $\begin{array}{c}\text { Standardized } \\
\text { Coefficients }\end{array}$ & Uji-T & $\begin{array}{l}\text { Probabilitas } \\
\text { (Sig. a } 0,05 \text { ) }\end{array}$ \\
\hline Constant & $-0,017$ & & $-1,570$ & 0,205 \\
\hline $\mathrm{KSV}\left(\mathrm{X}_{1}\right)$ & 0,233 & 0,256 & 10,185 & 0,000 \\
\hline $\mathrm{KUA}\left(\mathrm{X}_{2}\right)$ & 0,271 & 0,304 & 9,578 & 0,000 \\
\hline $\operatorname{KUAP}\left(\mathrm{X}_{3}\right)$ & 0,243 & 0,495 & 14,998 & 0,000 \\
\hline
\end{tabular}

Output SPSS V.22, (2017)

Hasil pengujian hipotesis masing-masing (parsial) varibel penelitian terbukti bahwa konservatisme akuntansi berpengaruh signifikan terhadap kualitas laba sebesar 23,3\%. konservatisme akuntansi dengan ukuran akrual dalam mekanisme corporate governance berpengaruh signifikan terhadap kualitas laba sebesar $27,10 \%$ dan konservatisme akuntansi dengan ukuran nilai pasar dalam mekanisme corporate governance berpengaruh signifikan terhadap kualitas laba sebesar $24,3 \%$

Hasil pengujian hipotesis secara bersamaan (simultan) variabel, bahwa hipotesis nilai $F_{\text {hitung }}$ sebsesar 864,260 sedangkan nilai signifikan F-nya adalah sebesar 0,000 yang artinya bahwa nilai signifikan $\mathrm{F}$ lebih kecil dari $a=0,05$ maka hipotesisis ini membuktkan bahwa Konservatisme Akuntansi, Konservatisme Akuntansi Dengan Ukuran Akrual dan Konservatisme Akuntansi Dengan Ukuran Nilai Pasar berpengaruh signifikan terhadap kualitas laba tidak dapat ditolak pada tingkat nilai $\alpha=0,05$. Dalam model persamaan regresi berganda diformulasikan :

$Y=-0,017+0,233 \mathrm{KSV}+0,271 \mathrm{KUA}+0,243 \mathrm{KUAP}+\varepsilon$.

\section{DAFTAR PUSTAKA}

Ahmed dan Duellman (2007). Accounting Conservatism And Board Of Director Charateristics: An Empirical Analysis. Journal of Accounting and Economics

Belkoui, Ahmed Riahi (2007), Teori Akuntansi, Edisi 5. Jakarta: Salemba Empat.

Febiani, Siska. 2012. Konservatisme Akuntansi, Corporate Governance, dan Kualitas Laba. Jurnal IImiah Mahasiswa Akuntansi, 1(2).

Febiani, Siska (2012), Konservatisme Akuntansi, Corporate Governance, Dan Kualitas Laba (Studi Empiris Pada Perusahaan Manufaktur di BEI) Jurnal IImiah Mahasiswa Akuntansi - Vol. 1, No. 2, Maret 2012 
Gul, Ferdinand A, dan Bin Srinindhi et al. (2002), The Asian Financial Crisis, Accounting Conservatism and Audit Fees: Evidence From Hong Kong. Working Paper.

Handojo, Irwanto.2012. Sekelumit Konservatisme Akuntansi. Media. 1-12

Indrawati, Novita dan Yulianti, Lilla (2010), Mekanisme Corporate Governance dan Kualitas laba. Pekbis Jurnal, 2(2), hal: 283-291.

Lo, Eko, W. (2005). Pengaruh Tingkat Kesulitan Keuangan Perusahaan Terhadap Konservatisme Akuntansi." Simposium Nasional Akuntansi VIII. Solo.

Paulus, Christian and Hadiprajitno (2011), Analisis Faktor-Faktor Yang Mempengaruhi Kualitas Laba.

Rachmawati, Andri dan Triatmoko Hanung (2007), Analisis Faktor-Faktor Yang Mempengaruhi Kualitas Laba Dan Nilai Perusahaan. Simposium Nasional Akuntansi X Universitas Hasanudin Makasar

Rika, Rindu Gamayuni (2012), Relevansi Kinerja Keuangan, Kualitas Laba, Intangible Asset, dengan Nilai Perusahaan, Jurnal Trikonomika Volume 11, No. 2, Desember 2012, Hal. 119 136. ISSN 1411-514X. Fakultas Ekonomi Universitas Lampung

Siallagan, Hamonangan dan M. Machfoedz (2006), Mekanisme Corporate Governance, Kualitas Laba dan Nilai Perusahaan. Simposium Nasional Akuntansi (SNA) IX Padang.

Sari, C. dan Adhariani, D. (2009), Konservatisme Perusahaan di Indonesia dan Faktor-Faktor yang Mempengaruhinya. Simposium Nasional Akuntansi XII, Palembang, November 2009.

Sadidi, Mehdi, Ali Saghafi, and Shahin Ahmad (2011), Accounting Conservatism and the Effect of Earning Quality on the Return of Assets and Stock Return. Journal of Accounting Knowledge.2 (6).

Triatmoko, Hanung (2007), Faktor-Faktor Yang Mempengaruhi Kualitas Laba Dan Nilai Perusahaan Simposium Akuntansi Nasional X Makasar.

Tuwentina, Putu dan Gede, Dewa Wirama (2014), Pengaruh Konservatisme Akuntansi Dan Good CorporateGovernance Pada Kualitas Laba. E-Journal Akuntansi Universitas Udayana ISSN: 2302 - 8556. Vol. 8.2 hal: $185-201$.

Veronica, Ellen (2013), Analisis Pengaruh Konservatisme Akuntansi Terhadap Kualitas Laba Akrual Yang Dimoderasi Oleh Good Corporate Governance Pada LQ 45 Di Bursa Efek Indonesia (BEI). Jurnal Audit dan Akuntansi Fakultas Ekonomi Universitas Tanjungpura Vol. 2, No. 1, Agustus 2013 Hal. 31-58

Watts, R.L. (2003), Conservatism in accounting part l: explanations and implications. Journal of Accounting and Economics. 207-221.

Wardhani, Ratna (2008), Tingkat Konservatisme Akuntansi di Indonesia dan Hubungannya dengan Karakteristik Dewan Sebagai Salah Satu Mekanisme Corporate Governance, Simposium Nasional Akuntansi XI, Pontianak, Juli.

(2010), Tingkat Konservatisme Akuntansi Di Indonesia Dan Hubungannya Dengan Karakteristik Dewan Sebagai Salah Satu Mekanisme Corporate Governance. Universitas Indonesia

Watts, Rose L. (2003), Conservatism in accounting Part II : Evidence and Research Opportunities. Accounting Horizon. Vol.17. N0.4. Pp 287-301 